\title{
IDIOPATHIC EXTREME OSTEOPOROSIS, ESPECIALLY OF THE SPINAL COLUMN AND THORACIC CAGE, WITH COLLAPSE OF FRONT OF CHEST
}

BY

\author{
H. C. LAUBER, F. PARKES WEBER, and J. G. GREENFIELD
}

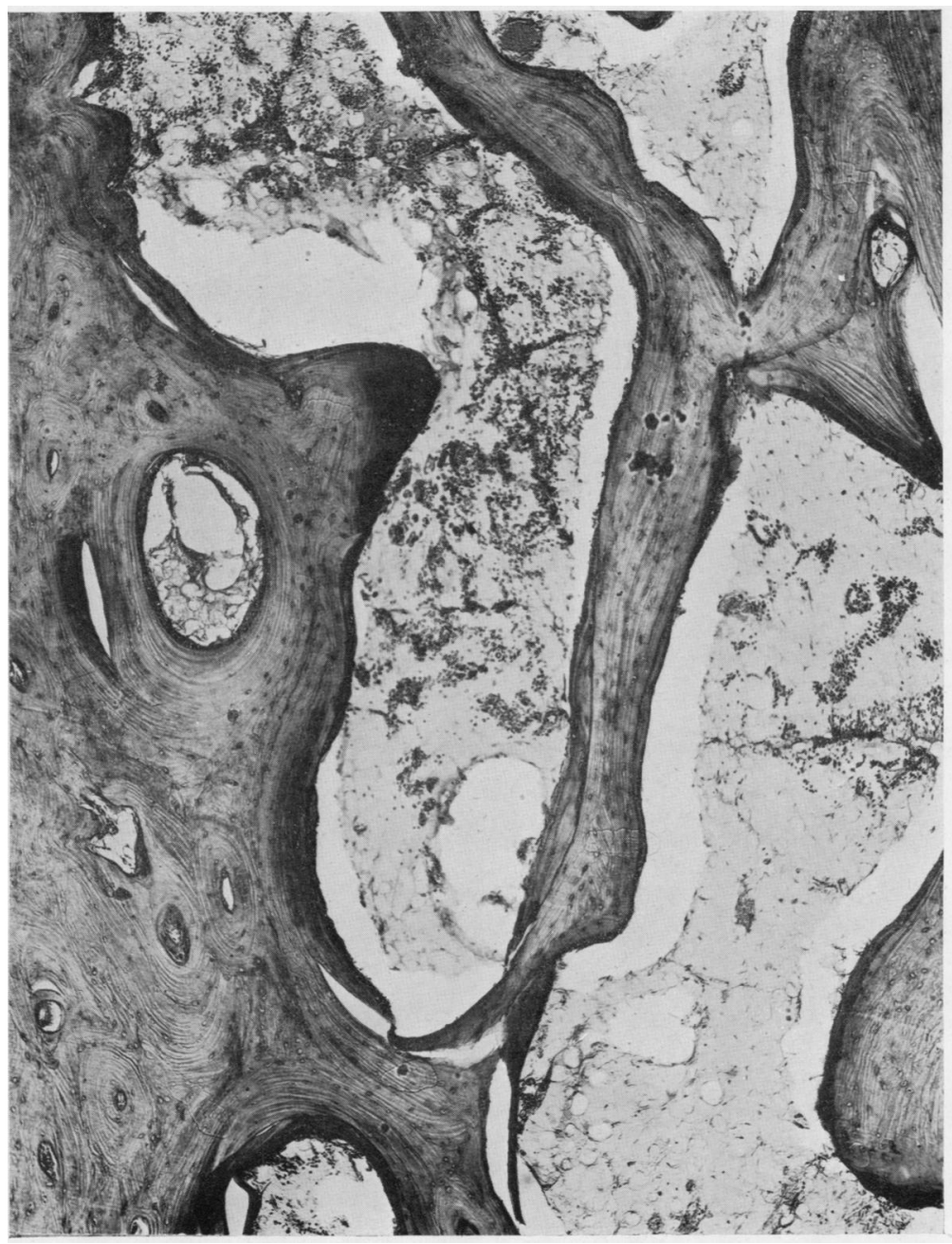

Fig. 1.-Section of skull showing rather thinned trabeculae of bone in diploe and partial disappearance of marrow cells. $\times 55$.
By "idiopathic" we mean of unknown causation. Burrows and Graham (1945 and 1947) describe a condition of spinal osteoporosis of unknown causation due to deficient ossification, affecting adults above 30 years of age, mainly women of 55 to 80 , but also men, commonly between 40 and 70 . Though the cause is unknown, it is suggested that it may possibly be related to slight dietary deficiency of calcium, phosphates, and ascorbic acid, but it is not due to deficiency of vitamin $D$. With calcium medication, they say, the symptoms improve, but there is little or no demonstrable improvement in regard to the osteoporosis.

They write: "Although generalized osteoporosis can sometimes be demonstrated, a material degree of porosis is confined to those bones, which, in the adult, contain red bonemarrow, namely, those of the spine, limb girdles, and thoracic cage. Only the lumbar and thoracic vertebrae undergo sufficient porosis to suffer material deformity." Our present case differed from all the severe ones to which Burrows and Graham (1947) refer, inasmuch as the actual bony collapse was relatively slight in the vertebral column, but so extreme in the 


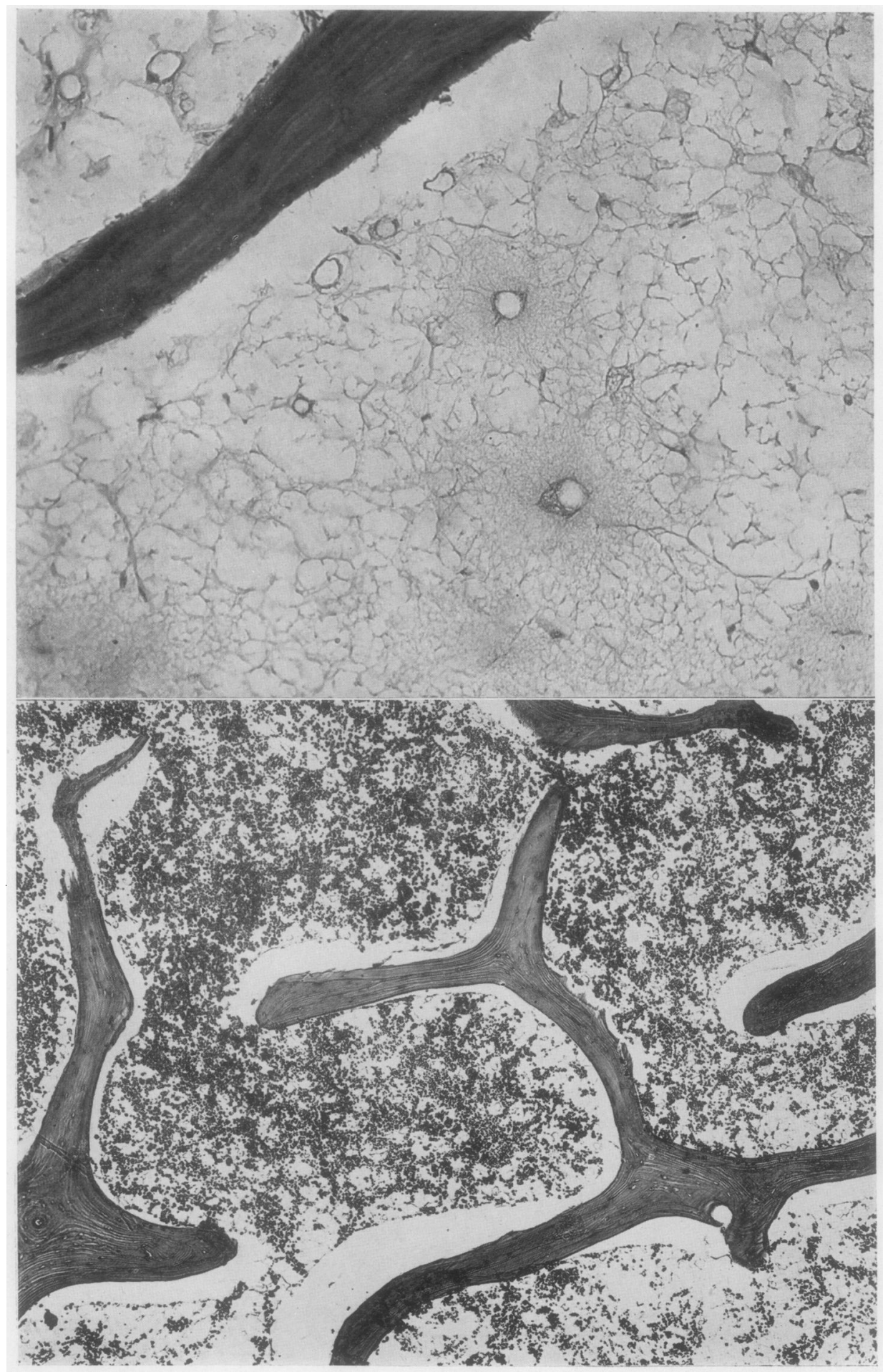


thoracic cage as to cause collapse of the front wall and falling in of the sternum.

\section{Account of the Case}

The patient, a manufacturer, aged 44 years, was admitted to hospital under Dr. H. C. Lauber on Nov. 12, 1943.

HistoRY.-The family history was not relevant. There were no brothers or sisters. In 1923: " chronic cholecystitis with hypochlorhydria" had been diagnosed (dislike of fatty food, blown-up feeling, flatulence). Since 1930 be had suffered on and off from "fibrositis". In 1937 a tumour of the brain was diagnosed by Dr. H. Cohn and operated on by Sir Hugh Cairns. An oligodendroglioma was removed. After that the patient felt well, except that in 1940 he suffered from sinusitis.

Since January, 1943, he had from time to time noticed pain in his back, for which he had massage. The pain gradually got more severe, and in October he noticed that he could lie in a certain position only and that the pain was most pronounced on getting up in the morning. At the beginning of November, 1943, the pain was especially felt in his right side, and he went to hospital with the suspicion of having pleurisy.

Condrion In Hosprtal.- He was a thinnish, palelooking man without dyspnoea and without cyanosis. Cardiovascular system, chest organs, abdomen, and central nervous system were normal. The dorsal and lumbar spine was stiff, and most painful when bending down or sideways. The joints of arms and legs were normal, and so was the temperature. Cholecystography showed that the gall-bladder did not fill. The Wassermann reaction was negative. The erythrocyte sedimentation rate was $28 \mathrm{~mm}$. ( 2 hours' average). The urine contained a trace of albumin, no sugar, a few hyaline casts, and no Bence-Jones protein.

The blood count was: haemoglobin 70 per cent.; erythrocytes $3,760,000$ per c.mm.; colour index, 0.93; leucocytes 9,600 per c.mm. The blood calcium was $9.5 \mathrm{mg}$. per $100 \mathrm{c.cm}$.

Radiographic examination of the spine was performed by Dr. Roth, who found partial collapse of the tenth dorsal vertebra and osteoporosis of the vertebral column. The skull showed marks of the previous operation.

In December, 1943, the patient had a spell of partial mental disorientation and drowsiness lasting for two weeks. On Dec. 6 the urine showed no trace of albumin or sugar; the blood-urea was $122 \mathrm{mg}$. per $100 \mathrm{c.cm}$. On Dec. 15 there was a trace of albumin in the urine, and also a few hyaline and granular casts. The blood urea was $137 \mathrm{mg}$. per $100 \mathrm{c.cm}$.

Urological examination (Dr. Dannheisser) did not show signs of obstructive uraemia. Fluid intake was $55 \mathrm{oz}$., and fluid output $48 \mathrm{oz}$.

At the end of December the blood urea was $103.6 \mathrm{mg}$. per $100 \mathrm{c.cm}$.

By January, 1944, the patient recovered from this uraemic condition. He complained of increasing pain in the back and chest on and off. His anaemia increased; his strength deteriorated, though his appetite was very good. On Jan. 15 the blood count was: haemoglobin 40 per cent.; erythrocytes $1,980,000$ per c.mm. of blood; colour index 1.02 ; leucocytes 7,800 per c.mm. The differential count (per cent.) was: neutrophils 36 , neutrophils stab. 8, neutrophils juv. 1 , lymphocytes 51 , monocytes 2 , eosinophils 2 (macrocytosis, hyperchromia, anisopoikilocytosis).

In the same month the urine was acid with a specific gravity of 1012; there was a trace of albumin, but no Bence-Jones protein. Microscopic examination revealed hyaline and cellular casts and leucocytes.

On Feb. 12 the blood count was: haemoglobin 42 per cent.; erythrocytes $2,160,000$ per c.mm. of blood; colour index 0.98 ; leucocytes 6,900 per c.mm. Total protein in the blood: $6 \cdot 2$ per cent.

By March, 1944, his condition had not altered much; there was further loss of flesh in spite of a diet high in calories. On Mar. 15 the blood count was: haemoglobin 52 per cent.; leucocytes 6,100 per c.mm. of blood. The differential count (per cent.) was: neutrophils 47, neutrophils stab. 2, neutrophils juv. 1, lymphocytes 47 , monocytes 3.

The leucocytes showed toxic granulation, and the erythrocytes hypochromia with anisocytosis. The blood urea was $65.4 \mathrm{mg}$. per c.cm.

Radiographs were taken of the thorax, spine, pelvis, and femur: all bones were shell-like and showed advanced changes. There was spontaneous fracture of one rib, and gross changes were noted in the skeleton of the chest wall.

Repeated examination showed a trace of albumin in the urine, but no Bence-Jones protein.

On May 25, 1944, the blood count was: haemoglobin 46 per cent.; erythrocytes $2,680,000$ per c.mm. of blood; colour index 0.80 ; leucocytes 7,100 per c.mm. The differential count (per cent.) was: neutrophils 57, lymphocytes 40 , monocytes 1 , basophils 2 . There was toxic granulation and aniso-poikilocytosis.

Unfortunately the blood which was taken for estimation of phosphatase and phosphorus was lost on two occasions, and these important data are therefore missing.

On Aug. 28, 1944, the blood count was: haemoglobin 54 per cent.; erythrocytes $3,240,000$ per c.mm. of blood; colour index 0.80 ; leucocytes 7,300 per c.mm. The differential count (per cent.) was: neutrophils 40, lymphocytes 56, promyelocytes 3 , plasma cells 1 .

There was fracture of another rib, and the patient was feeling weaker and was much thinner. There was temporary corneal erosion, much pain when moving, and "falling in" of the sternum. He died on Sept. 13, 1944.

Treatment.-Between Nov. 12, 1943, and Jan. 19, 1944, he had "fersolate"; vitamin D (calciferol), and injections of colloidal calcium. In January, 1944, a leather jacket was given to him, but it was never worn. From May 25, 1944, radiostoleum and calcium were given by mouth. Beginning on June 18 he received twenty injections of colloidal calcium, after which, from July 20, he had twenty injections of calcium (Sandoz).

On Aug. 25, 1944, morphine was started.

NeCROPSY.-There was extreme emaciation. The organs were pale and very reduced in size and weight; the bones of the thoracic cage and vertebral bodies were shell-like, and there was osteoporosis of all bones, 
especially of the spine. The bone-marrow of one of the iliac bones was examined and found macroscopically to resemble that of the ribs. The bone-marrow was partly gelatinous. The macroscopic appearance of the internal organs was normal except for their small size. The weight of some of the organs was as follows:

$\begin{array}{lllrr}\text { Brain } & . & \ldots & 1,250 \mathrm{~g} . & \begin{array}{r}\text { Normal average } \\ \text { Heart }\end{array} \\ \text { Liver } & . & . & 200 \mathrm{~g} . & 300 \mathrm{~g} . \\ \text { Spleen } & . & 700 \mathrm{~g} . & 1,600 \mathrm{~g} . \\ \text { Kidney (left) } & . . & 250 \mathrm{~g} . & 150 \mathrm{~g} . & 150 \mathrm{~g} .\end{array}$

The following were sent for pathological examination to Dr. J. G. Greenfield, at the Chase Farm Hospital, Enfield: pieces of spleen, liver, and aorta; the urinary bladder with the prostate gland, the thyroid gland, a suprarenal gland, and the pituitary gland; the left kidney and brain; the greater part of the vertebral column with ribs attached; part of the right ileum; the central part of the right femur (with gelatinous bone-marrow), the sternum, with the whole front of the chest; and the calvarium. Unfortunately the pituitary gland was lost.

\section{Dr. Greenfield's Histological (AMENDED) REPORT}

Spleen.-In the spleen there was thickening both of the fibrous tissue septa and of the adventitia of the blood vessels. No Malpighian bodies were seen. The arterioles were thick-walled but without hyaline change in the media. There was diffuse fibrosis of the pulp, and a very large amount of blood pigment collected in masses or in smaller intracellular collections. There was a diffuse increase in the numbers of lymphocytes and plasma cells in the sinus system.

Liver.-The liver cells also contained a large amount of blood pigment, most of which gave the Prussian Blue reaction; swollen Kupffer cells were also seen full of Prussian blue granules. There was also some excess of bile pigment in the liver cells. There was no excess of lymphocytes in the portal tracts.

Aorta. - The aorta was normal. The thyroid showed diffuse fibrosis but no evidence of hyperactivity.

Kidney.-In the kidney there was a diffuse deposition of small calcified knots in the interstitial fibrous-tissue, both in the cortex and medulla. Some small wedges of degeneration and fibrosis were seen passing in from the capsule. The smaller arteries showed slight concentric and eccentric thickening of their walls, but no hyaline degeneration of the media. Some of the glomeruli showed slight hyaline changes.

Brain.-In the area of the brain from which the tumour had been removed there was softening of the subcortical white matter over a limited area, with collagenous and neuroglial scarring, calcium deposition in this and the zone immediately surrounding it, and the presence of many granular and other phagocytic cells.

Prostate.-The prostate showed an excess of small calculi (prostatic sand) but no other abnormality.

Bones.-In the dark areas the skull contained fairly large Haversian canals which were filled chiefly with thin areolar tissue, but many contained also rather sparse marrow cells (" Gelatinous degeneration of bone-marrow"). There was some irregularity in the lines of ossification, but no evidence of osteoid tissue. The vertebral bodies showed extreme osteoporosis, only a very thin outer shell of bone remaining, with some thin spicules of bone in the medulla. Here the marrow cells were in places very sparse and in places absent. In the latter areas the connective tissue was of finer character than in the skull.

\section{Discussion}

Extreme spinal and thoracic osteoporosis, with resulting deformity, may, as Burrows and Graham (1947) point out, be found in known diseases causing osteoporosis, and similar deformities may, as is well known, occur in osteomalacia. One of us (Parkes. Weber, 1897), under the heading " general lymphadenosis of bones, one form of multiple myeloma", described the case of a man, aged 61 years, whose spinal column and thoracic cage were infiltrated and largely replaced by some kind of a malignant very vascular neoplasm. The bones and microscopic sections were carefully examined by the late Prof. S. G. Shattock, by whom specimens were arranged and described in the museum of the Royal College of Surgeons in London (catalogue, $2115 \mathrm{D}, 1640 \mathrm{E}, 1640 \mathrm{~F})$. No similar case has been met with since then. The ribs were all converted into delicate tubes formed of periosteum with only a thin imperfect shell of bone; they were stuffed full of the new growth.

In regard to the collapse of the front wall of the thoracic cage and the consequent falling in of the sternum, one of us (Parkes Weber) has seen a similar appearance in a young man, but that was the case fully described by Graham and Stansfeld (1946) under the heading "A Hitherto Undescribed Lipoidosis simulating Rheumatoid Arthritis".

Whether cases similar to those described under the heading "Milkman's disease" are in any way related to idiopathic spinal osteoporosis seems to be answered in the negative by McCance's paper (1947) on "Osteomalacia with Looser's nodes (Milkman's Syndrome) " due to abnormal resistance to absorption of vitamin $\mathrm{D}$. The term Looser's zones is probably preferable to Looser's nodes.

A question which arises, and cannot yet be answered, is whether cases of severe or less severe idiopathic spinal osteoporosis are related in any way to the ordinary cases of generalized osteoporosis in old age (Kesson and others, 1947). (See also Black and others, 1941, and Merklen, 1936.)

As to the cause of the haemolytic anaemia in the present case, it seems highly probable that it was in some way connected with, if not directly due to, the changes in the bone-marrow.

It is unfortunate that owing to wartime difficulties 
our data are incomplete with regard to the blood phosphorus, the blood phosphatase, and histological examination of the pituitary and parathyroid glands. However, it is unlikely that the temporary renal disturbance, evidenced especially by high blood urea, caused secondary hyperparathyroidism; no excess of blood calcium was discovered.

\section{Summary}

The case was that of a man, aged 44 years, who in January, 1943, commenced to suffer on and off from pain in the back. Signs of severe osteoporosis of the vertebral column and ribs gradually increased, and were accompanied by considerable anaemia. He died in September, 1944. The necropsy showed osteoporosis, especially of the vertebral column and chest wall. As in similar (though somewhat less extreme) cases recorded in the literature of the subject, no cause was discovered, and all treatment was unavailing. The actual bony collapse was less in the vertebral column than in the thoracic cage, where falling-in of the sternum was a result.

\section{REFERENCES}

Black, J. R., Ghormley, R. K., and Camp, J. D. (1941). J. Amer. med. Ass., 117, 2144.

Burrows, H. J., and Graham, G. (1945). Quart. J. Med. $N, S ., 14,147$.
Burrows, H. J., and Graham, G. (1947). Annals of the Rheumatic Diseases, 6, 129.

Graham, G., and Stansfeld, A. G. (1946). J. Path. Bact., 58, 545.

Kesson, C. M., Morris, N., and McCutcheon, A. (1947). Annals of the Rheumatic Diseases, 6, 146.

McCance, R. A. (1947). Quart. J. Med. N. S., 16, 33.

Merklen, P. (1936). Pr. méd., 44, 1443.

Weber, F. Parkes (1897). Trans. Path. Soc. Lond., 48, 169.

Ostéoporose Idiopathique Grave, Atteignant -Particulièrement la Colonne Vertébrale et la Cage Thoracique avec Effondrement Frontal du Thorax

\section{RÉSUMÉ}

Le malade était un homme, âgé de 44 ans, qui avait commencé, en janvier 1943, à souffrir de douleurs intermittentes dans le dos. Les symptomes d'ostéoporose grave de la colonne vertébrale et des côtes, accompagnée d'anémie très prononcée augmentèrent graduellement. Il est mort en septembre 1944. A l'autopsie on constata de l'ostéoporose, surtout de la colonne vertébrale et des parois thoraciques. De même que dans les cas analogues cités dans la littérature, on n'a pu en déceler la cause, et aucun traitement n'a donné de résultat. L'affaissement osseux était moins marqué dans la colonne vertébrale que dans la cage thoracique où il avait provoqué le renfoncement du sternum. 